\title{
Schriftgezag op het speelveld van de hermeneutische ethiek
}

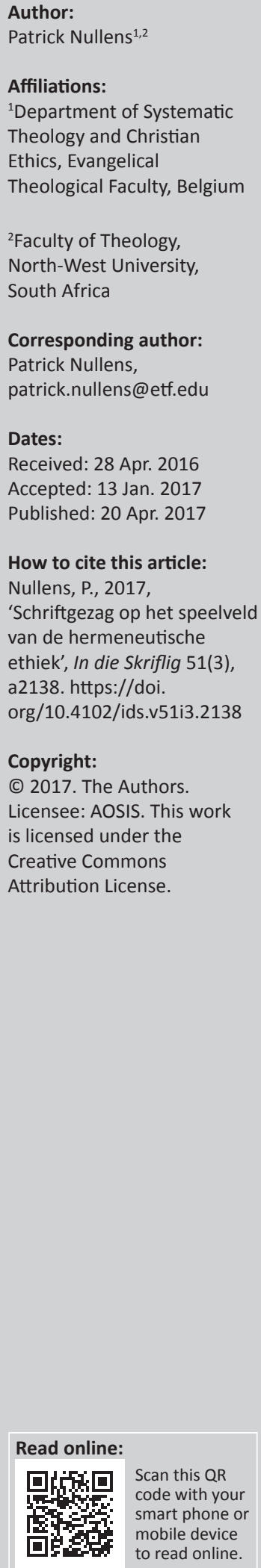

Scripture on the playground of hermeneutical ethics. As a tribute to Jan G. van der Watt, in this article I offer a reflection on the authority of Scripture in ethics, in attempted loyalty to the motto of our theological faculty: Fides Quaerens Intellectum.

The main thesis of this article is that ethics not only requires hermeneutics, but that the core task of ethics itself is interpretation.

From an evangelical-reformed perspective, I will present a phenomenological and hermeneutical model, inspired by thinkers such as Gadamer and Ricoeur, defining ethics itself as a hermeneutical exercise, an act of interpretation, inherent to life itself. Defining ethics as such will influence the way in which we will integrate Scripture in our moral discourse.

The playing field of hermeneutical Christian ethics is described by four points we will briefly discuss. Firstly, we will describe ethics as a philosophical and theological discipline with a hermeneutical task. Next, I offer three anchor points for the unique contribution of Scripture to this hermeneutical process: (1) faith as the entry point for interpreting Scripture as a source for Christian ethics; (2) the church in the world as the context in which one uses Scripture; and (3) in the Augustinian tradition, the double commandment of love as the ultimate rule of interpretation, the measure against which every text should be read.

Despite the fact that these three anchor points all have their negative counterparts (idolatry, individualism and resentment), they are vital to the interpretation of Scripture in Christian ethics. Pastors who use Scripture for moral direction have to be aware of the characteristics of moral

\section{Inleiding}

\section{Jan G. van der Watt}

In dit Festschrift wordt hulde gebracht aan onze collega Jan G. van der Watt. Van der Watt heeft niet alleen in Zuid-Afrika, maar ook hier in de Benelux een belangrijke invloed gehad, enerzijds door zijn onderzoek in de ethiek, anderzijds door het leggen van de brug tussen de academische wereld, de kerk en de maatschappij; een bewijs daarvoor is onder andere te vinden in de vele populaire en academische werken die hij tot dusver heeft gepubliceerd. In een recente publicatie bracht Van der Watt hulde aan een van zijn eigen mentoren, Abraham Malherbe, onderzoeker aan Yale University en zelf een bruggenbouwer tussen de academie en de kerk. Van der Watt stelt: 'For Abe his faith remained central in his life, right to the end. He had the ability to balance the possible tension between his faith and his academic activity' (2015:20). Zo bleven dus zowel Malherbe als Van der Watt zelf trouw aan Anselmus' motto Fides Quaerens Intellectum, en hadden zo een significante invloed op studenten en collega's die volgens hetzelfde motto wilden leven. Van der Watts werk in de ethiek wordt goed erkend in de Europese context, en om die reden biedt dit artikel een reflectie op een ethisch thema, zij het dan vanuit een systematisch-theologische hoek benaderd, en waar van toepassing in gesprek gaand met het gedachtegoed van Van der Watt.

\section{'Neem en lees!' Welke rol geven we aan de Bijbel?}

Welke rol geven we als evangelisch-gereformeerde christenen aan de Bijbel wanneer het gaat om ons morele leven? Op welke wijze is dit bijzondere boek het instrument van Gods Geest om levens concreet te veranderen? Het bekeringsverhaal van de kerkvader is alom bekend, maar de morele dimensie van het verhaal wordt soms onvoldoende onderkend. De tweeëndertigjarige Augustinus verkeerde in een toestand van innerlijke rusteloosheid toen hij in de tuin naast zijn woning in Milaan een kinderstemmetje hoorde zingen: ‘Tolle, lege! Tolle lege!' ('Neem en lees!'). 
Hij nam de Schrift, en de eerste passage waar zijn ogen op vielen was:

Laten wij, als op klaarlichte dag, op een gepaste wijze wandelen, niet in zwelgpartijen en dronkenschappen, niet in slaapkamers en losbandigheden, niet in ruzie en afgunst. Maar bekleed u met de Heere Jezus Christus, en verzorg het vlees niet om begeerten op te wekken. (Rom 13:13, 14; alle geciteerde bijbelpassages uit Herziene Statenvertaling)

De selectie van deze passage is opmerkelijk. Voor Augustinus was het alsof Gods Geest heel concreet tot hem sprak over zijn levenswandel. Deze woorden brachten in hem een bevrijding uit een lange strijd van twijfel en intellectuele worstelingen teweeg: 'Verder wilde ik niet lezen en dat was ook niet nodig. Want terstond, toen ik deze woorden ten einde gelezen had, stroomde als het ware het licht van de gemoedsrust mijn hart binnen en alle duisternis van twijfel vlood weg' (Augustinus 1982:175). Hoe mooi deze woorden ook klinken, het resultaat was niet alleen een innerlijke gemoedsrust. Het gevolg was een nieuwe ascetische levensstijl, een nieuwe ethiek van de Geest van Christus en niet langer die van het egocentrische 'ik'. De Schrift wees Augustinus een nieuwe weg tot levensgeluk, de ontmoeting met God.

De bekering van Augustinus kan omschreven worden als een hermeneutische wending waarbij hij plots zichzelf en de wereld rondom hem anders zag en beleefde: de woorden die hij las waren immers woorden van licht. In dit artikel staan we stil bij dit hermeneutische proces waarbij wij niet alleen de Schrift lezen maar hoe ook de Schrift ons leest en er door het werk van Gods Geest een gewetensonderzoek plaatsvindt waarbij de Schrift een transformerende kracht is. De Schrift overstijgt ieder menselijk kennen en is een kracht van God die tot in ons diepste innerlijke leven doordringt en al onze overleggingen en gedachten beoordeelt (Heb 4:12). Zo'n twaalf eeuwen na Augustinus bevestigden de reformatoren deze fundamentele christelijke boodschap: dat de Schrift Gods boek is, geloofwaardig in zichzelf (autopistie) en het hoogste gezag in leer en leven. Een externe menselijke bekrachtiging van de Heilige Schrift was overbodig. De Heilige Geest legt in ons hart een intern getuigenis af dat dit Gods Woord is. Sterker nog, de Bijbel is duidelijk (persipicuitas Sacrae Scripturae) en legt zichzelf uit (Sacra Scriptura sui ipsius interpres).

Maar de moderniteit en de bijhorende bijbelwetenschappen brachten de positie van de Bijbel als één goddelijk boek, geïnspireerd door Gods Geest, in diskrediet. Zo spreekt bij voorbeeld Harry Kuitert over de 'papieren paus' van de protestanten wiens gezag door de moderne bijbelwetenschap werd ontmaskerd (1981:65-82). Deze kritiek raakt een tere plek en blijft bij velen van ons nazinderen. De relatie tussen de exegese van bijbelse teksten en ethiek als academische discipline is complex en vraagt om een nauwkeurige en uitvoerige theologische reflectie (Nullens 2006:235-284; voor een inleidend literatuuroverzicht zie Birch 2011). De belangrijkste respons was die van een hermeneutisch verantwoorde lezing van de Bijbel met alle aandacht voor het menselijke karakter van de teksten, de unieke historische context, de diversiteit van de bijbelboeken, de eigenheid van de taaluitdrukkingen, en de oorspronkelijke betekenis van de tekst voor de toehoorders. Het is nu een gegeven dat men zorgvuldig met de oude teksten moet omgaan en daarenboven is er een groeiend bewustzijn onder evangelische theologen dat we de Schrift dienen te lezen vanuit een breder theologisch en heilshistorisch kader. Maar is dit voldoende? Niet alleen onze wetenschappelijke benadering van de Schrift, maar ook onze kijk op wat ethiek eigenlijk als vakdiscipline doet (en niet doet) is bepalend voor hoe we de bijbelse tekst integreren in ons moreel discours.

Deze bijdrage tracht het speelveld van een hermeneutische ethiek op verkennende wijze te omschrijven. Het uitgangspunt is dat niet alleen ons bijbelgebruik, maar de ethische reflectie zelf een hermeneutische bezigheid is, die bovendien onlosmakelijk bij het leven hoort. De eerste opdracht van ethiek is die van interpretatie. Hierbij is er een verschuiving van aandacht van de normerende functie van de Schrift naar de vormende kracht van Gods Woord door de werking van zijn Gods Geest (zie bijv. Thiselton 1992; Vanhoozer 2005).

Nadat we de hermeneutische opdracht van ethiek hebben vastgesteld, bespreek ik vervolgens drie ankerpunten voor het specifieke gebruik van de Schrift in dit hermeneutische proces: geloof is als het ware de toegangspoort waarlangs we de Schrift gaan zien als een bron voor christelijke ethiek; de kerk die in de wereld staat de noodzakelijke context waarin onze interpretatie plaatsvindt; en ten slotte, in de traditie van Augustinus, de liefde als ultieme leesregel. Deze ankerpunten zijn bedoeld als algemene 'spelregels' voor schriftgebruik binnen een hermeneutische ethiek in een evangelischreformatorische context.

\section{De eerste opdracht: ethiek als hermeneutische handeling}

Van der Watt merkt enerzijds op: 'Etiek gaan oor hoe 'n mens behoort op te tree, oor wat regte of verkeerde optrede is. Wat is God se wil as dit kom by praktiese dinge' (2014:276). Anderzijds ziet hij ook de uitdaging, dat '[D]aar is natuurlik baie benaderings tot etiek' en de hedendaagse en verleden 'Situasies is dikwels kompleks en uiteenlopend' (2014:280). Los van het feit dat de Bijbel onze primaire bron is, is het ook een boek met een veelvoud aan contexten, stemmen en perspectieven ('inter-kanonieke gesprek'; cf. Deut 24:1-4 vs. Mark 10:2-12) met een impliciete hiërarchie van waarden die ons uitdaagt om hermeneutisch te reflecteren op de manier waarop een bijbelse ethiek dient te worden geïnterpreteerd en toegepast (2014::280).

Dus, voordat we theologisch kunnen spreken over de rol van de Bijbel binnen de ethiek, dienen we eerst de bredere vraag te beantwoorden naar de opdracht van ethiek als vakdiscipline binnen de menswetenschappen. Hoe we deze vraag 
beantwoorden bepaalt immers onze verwachtingen tegenover de Bijbel als primaire bron voor een christelijke ethiek. De klassieke Socratische vraag waarover het in de ethiek moet gaan is: hoe moeten we leven? Vanuit dit brede perspectief heeft ethiek betrekking op levenskunst en samenlevingskunst. Het is geen strikte wetenschap, maar vooral wijsheid, phronēsis, een praktische wijsheid (lat. Prudentia). Het Aristotelische onderscheid tussen '(theoretische) kennis' (epistêmê en sophia), 'vakmanschap' (technê) en 'wijsheid' of praktisch redeneren (phronēsis) is nog altijd bijzonder relevant. Gadamer bekritiseert hier de eenzijdige aandacht voor de mathematische methodiek van de wetenschap. Hij schept hierbij ruimte voor een praktisch weten dat op concrete levenssituaties is gericht. Bij phronèsis gaat het vooral om een geestelijke houding die nauw verbonden is aan de deugden (Gadamer 2014:33-34). Vanuit de bijbelse achtergrond is ethiek een reflectie die hoort bij de chokmah, de wijsheid. Deze chokmah is een proces van praktisch redeneren, gericht op concrete keuzes en handelingen (Thiselton 2011:163-172). Dit betekent onder meer dat er in de complexiteit van het leven geen eenduidige antwoorden bestaan. Toch moeten we handelen, keuzes maken en onze verantwoordelijkheid opnemen. Bovenal is de chokmah een bepaalde manier van het ervaren van de werkelijkheid als Gods werkelijkheid. Het begin van wijsheid is dan ook het respect voor God, het geloof (Pred 9:10).

Zowel in zijn brede filosofische vorm als bijbels-theologisch is ethiek vooral een wetenschap van het interpreteren of een hermeneutische handeling. Onder hermeneutiek verstaat men de kunst van het nauwkeurig kijken en interpreteren van de werkelijkheid. Vooral sinds Martin Heidegger speelt de hermeneutiek een meer existentiële rol. Volgens Heidegger is Verstehen de centrale modus van het 'in-de-wereld' zijn (Dasein). Dit is niet een zuiver cognitief proces, maar eerder een existentieel gebeuren van openheid naar de wereld toe. Aansluitend hierop kan hermeneutiek worden gezien als een algemene methode uit de geesteswetenschappen, zoals aangegeven door Hans-Georg Gadamer in zijn massieve Waarheid en methode: 'verstaan is het zijnskarakter van het menselijke leven zelf' (2014:249). Daarom hoort het ook bij de brede vorming (Bildung) van ons menszijn. Deze Bildung hangt nauw samen met het begrip cultuur en verwijst naar de menselijke eigenschap om onze talenten en vermogens te ontwikkelen. In Bildung zit het woord 'beeld' ingesloten, en dit sluit volgens Gadamer aan op de oude traditie dat de mens naar Gods beeld is geschapen en dit nu 'in zijn ziel meedraagt en in zichzelf moet uitbouwen' (2014:24). Essentieel in Bildung, en daarmee ook in de opdracht van de geesteswetenschappen (waar ethiek onder valt) is de hermeneutische handeling: 'zichzelf en zijn particuliere doeleinden met afstand [te] bekijken betekent immers: ernaar kijken zoals anderen ernaar kijken' (2014:29).

Gelijkaardig stelt de Canadese cultuurfilosoof Charles Taylor dat de natuurwetenschappen ons niet ten volle laten zien wie de mens is; ze geven alleen feiten aan die vervolgens om interpretatie vragen. In dit proces van interpretatie zoeken we naar verbanden, waarderen we feiten en brengen deze ten slotte samen tot een groter geheel. Net als Gadamer schept ook Taylor een belangrijke ruimte voor de menswetenschappen in het algemeen, ethiek in het bijzonder, en wat ons betreft ook de theologie. De reden waarom er een verschil tussen mens- en natuurwetenschappen bestaat, komt voort uit de aard van de mens zelf: 'man is a self-interpreting animal ... he is always partly constituted by self-interpretation' (Taylor 1985:65). Interpretatie is altijd zelf-interpretatie en deze activiteit hoort bij de kern van de menselijke existentie. De manier waarop we onze werkelijkheid interpreteren is altijd historisch en contextueel. Volgens Taylor voelt de hedendaagse mens zich innerlijk geroepen een authentiek persoon te zijn. Hij ziet het ontwikkelen van het 'zichzelf zijn' als een morele plicht. In een postmoderne cultuur wordt authenticiteit verheven tot een kernwaarde die sterk onze morele interpretaties bepaalt. Hermeneutische ethiek gaat over een doordachte interpretatie van onze morele beleving en vertrekt vanuit onze morele intuitie en diepere drijfveren. Deze aandacht voor de geleefde ervaring wordt gewoonlijk als fenomenologisch geduid (Moran \& Mooney 2002). In dit opzicht kan een verband gelegd worden tussen de etymologie van 'ethiek' en de hermeneutische opdracht. Ethiek is afgeleid van het Griekse ethos en betekent oorspronkelijk woonplaats of gebruik (gewoonte). Door het interpreteren scheppen we ons samen een veilige woonplaats. Verwijzend naar Aristoteles stelt Paul van Tongeren (1994) het volgende antropologische feit vast:

Het eigenlijk menselijke is de logos, dat wil zeggen het vermogen om betekenissen te verstaan en te verstaan te geven. Mensen zijn dieren die zich slechts hierin van andere dieren onderscheiden, dat ze in hun leven betekenis ervaren en verstaan, die ze sprekend proberen te identificeren en te communiceren. (p. 67)

Van Tongeren ziet de logos niet exclusief als het redelijke vermogen, maar hij vat het begrip breder op als de menselijke capaciteit om betekenis te geven en vervolgens deze betekenis met elkaar te delen. Taal is het instrument voor zowel onze eigen interpretaties als voor het morele discours dat we onder elkaar houden. In de ethiek nemen we een reflectieve afstand van onze eigen morele ervaringen. In dit opzicht is ethiek een hermeneutiek van de morele ervaring, of van ons morele 'voorverstaan' (een germanisme van van Tongeren 1994:57). In dit proces van zelf-verstaan en zingeving spelen traditie en teksten een belangrijke bemiddelende rol. ${ }^{1}$

Volgens Ricoeur is de mens een vertellend wezen dat zich voortdurend oriënteert via narratieve structuren. ${ }^{2}$ We zijn als het ware een personage in het levensverhaal dat we over onszelf vertellen. Het is belangrijk dat we in dit verhaal de ander ontmoeten, tradities leren en buiten onszelf treden. We worden immers in een wereld geboren waarin al voor ons gesproken is, en waar we vanaf het begin worden aangesproken. Teksten zijn dragers van interpretaties en

1.Dit hermeneutische model sluit aan bij de pastorale theologie van $G$. Heitink. De eerste opdracht is altijd het begrijpen, dan pas volgt het verklaren en veranderen; zie Heitink (1993:174 e.v.).

2.Paul Ricoeur heeft in zijn lange loopbaan veel geschreven. Voor zijn ethische bijdrage kunnen we vooral verwijzen naar Paul Ricoeur (1990); voor een goede inleiding op zijn werk in verband met hermeneutiek en ethiek: Ricoeur (1986); voor inleiding op zijn werk in verband met hermeneutiek en ethiek: Ricoeur (1986); voor
de theologische betekenis van Ricoeur verwijs ik graag naar het proefschrift van Jansen (2002), en Stiver (2012). 
bevrijden ons uit een egocentrisch en tijdsgebonden verstaan. Wanneer we echt open staan verandert de tekst ons zelfverstaan. Zichzelf verstaan is verstaan voor de tekst en van deze de voorwaarden ontvangen van een 'zichzelf' dat anders is dan het ' $\mathrm{ik}$ ' dat begon te lezen. (Ricoeur 1986:31: 'Se comprendre, c'est se comprendre devant le texte et recevoir de lui les conditions d'un soi autre que le moi qui vient à la lecture.') Het ik is geen meester meer van zichzelf, maar wordt een leerling van de tekst, die zich laat vormen. Voor Ricoeur is dit een morele opdracht, juist omdat we uit onze eigen idolatrie, het gesloten ik, moeten worden bevrijd. Hiervoor is er een voortdurende oefening in vrijheid nodig, wat hij 'imaginatieve variatie' noemt. De tekst biedt ons een confrontatie met een diversiteit van modellen die ons uitdagen de nodige morele ruimte te scheppen en onze eigen posities voortdurend te heroverwegen. We spelen als het ware een rollenspel op basis van de tekst. Uiteindelijk moeten wedantotonszelfterug komeneninalleverantwoordelijkheid, als een verantwoordelijk ' $\mathrm{ik}^{\prime}$, een beslissing nemen. We kiezen uiteindelijk voor een bepaalde gezichtshoek en nemen weloverwogen onze verantwoordelijkheid op.

Het lezen van de Schrift vraagt om een innerlijke openheid, een vrijheid van interpretatie en discussie. Hierbij is juist het confronterende, het andere zo belangrijk. Zo komen sommige parabels van Jezus heel redelijk over, bijvoorbeeld die over de barmhartige Samaritaan (Luk 10), terwijl andere heel vreemd klinken en ingaan tegen ons primaire morele gevoel, denk bijvoorbeeld aan de late dagloners (Matt 20). Of iets als evident wordt gezien, zegt veel over ons eigen waardenkader. Zolang er duidelijke conventies zijn, worden de interpretatie van de werkelijkheid, het goede en kwade niet echt bevraagd. Het is pas wanneer die conventies in een crisis terecht komen dat we de ethische vragen radicaler gaan stellen. Deze veranderingen van sociale conventies zien we duidelijk in de seksuele ethiek. Ook hier gaat het in eerste instantie om het interpreteren van biologische feiten als geslachtelijk verkeer en concrete vormen van samenleven. Het is vervolgens via een bepaalde interpretatie dat onze waarneembare behoeften (feiten) de status van rechten kunnen krijgen (van Tongeren 1994:59). We beantwoorden morele vragen eerst intuitief en vanuit een sociale consensus, alvorens we ze theoretisch bevragen in een filosofisch discours. Paul van Tongeren verwijst in dit verband naar het werk van Bernard Williams (1985): Naast de ethische theorie, die een wetenschappelijke a posteriori reflectie is, hebben we nood aan een ethisch denken. De morele overtuigingen gaan vooraf aan de filosofische reflectie. Dit voorwetenschappelijk ethisch denken vormt de wereld waar we in willen wonen, waarin we met elkaar in vrijheid leven (van Tongeren 1994:57). Ethiek is niet alleen interpreteren; het is vooral samen interpreteren en dus dialoog met anderen. Deze dialoog over interpretaties hoort bij ons sociaal menszijn, het zooion politikon. Voor dit proces van samen interpreteren is een ander soort kennis nodig dan wetenschappelijke kennis van feiten en inzicht in causale verbanden.

Het wat filosofisch omschrijven van ethiek als hermeneutische handeling zegt veel over hoe ethiek functioneert, maar het laat ons in de steek wanneer het gaat om concrete inhoud en het biedt ons geen duidelijke argumentatie voor een bepaalde specifieke levenswijze. Uiteindelijk geeft de filosofie dus geen antwoord op de Socratische vraag: hoe te leven? Johan Verstraeten merkt kritisch op: 'The ethical method of many handbooks seems to end where the most crucial aspects of moral formation and judgment begins: the choice for (particular) interpretation of the good life and the joint hierarchization of values' (Verstraeten 2000:4). Er is dus altijd een soort geloofssprong, een 'voor-verstaan' dat onze interpretaties bepaalt. De filosofie geeft ons inzicht in de structuur en de rol van de hermeneutische handeling, maar schiet tekort wanneer het gaat over de concrete invulling.

Het is tegen de achtergrond van de hermeneutische handeling dat de klassieke ethische theorieën moeten worden geplaatst (utilitarisme, deontologische ethiek, waardenethiek, deugdenleer enz.). De ethische matrix maakt gebruik van de verschillende morele theorieën als manieren van kijken en verstaan (Nullens \& Michener 2010). De verschillende theorieën zijn redeneermodellen die gebruikt worden als hulpmiddelen bij het verstaan en interpreteren van de ethische dimensie van de werkelijkheid (van Tongeren 2012:63-65). Kenmerkend voor deze hermeneutische matrixmethode is dat men geen van deze modellen verabsoluteert als de meest juiste en enige benadering, wat een reductie zou zijn van de complexe werkelijkheid en een verloochening van de rijkdom van onze eigen morele intuïtie. We voegen feiten, principes, gevolgen, waarden en verwachtingen samen tot een zingevend verhaal. Het doordenken van al deze modellen in een concrete situatie is tevens een vorm van imaginatieve variatie en hoeft niet noodzakelijk tot moreel relativisme te leiden. ${ }^{3}$ Ook hier gaat het om het interpreteren van feiten en blijft een coherente wetenschappelijke discipline noodzakelijk. Uiteindelijk moet men na het hermeneutische proces zijn eigen geweten volgen. Het is goed om te beseffen dat we ook in de Bijbel zelf een grote diversiteit van ethisch redeneren terugvinden. Zo zullen de wijsheidsliteratuur, de verhalende gedeelten en de gebodsteksten een moreel thema op een verschillende manier behandelen.

Dit brede verstaan van ethiek als hermeneutische handeling en een taalgebeuren vraagt om een wat concretere theologische inkleuring. De christelijke ethiek handelt uiteindelijk over Gods wil voor ons, en niet onze eigen wil gebruikmakend van een god die ons past.

\section{Drie ankerpunten}

\section{De bron van interpretatie: Geloof}

'Zo is dan het geloof uit het gehoor en het gehoor door het Woord van God' (Rom 10:17). De apostolische prediking 'Christus als Heer' vormt de bron van onze ethiek. Ons primaire antwoord op het evangelie is dat van bekering en geloof. Geloof! is het eerste gebod. Zonder geloof blijft de Schrift een gesloten boek en houden de morele claims geen steek. Door de nadruk op geloof wordt het antropocentrische ethische matrix en dit op het terrein van 'business ethics', zie Nullens (2014). 
van de wijsgerige ethiek verlaten en komt Gods geopenbaarde wil in het middelpunt te staan. Hier ligt een scherpe scheidingslijn: De mens zelf is niet bekwaam om het goede te kennen en alleen door geloof krijgt hij toegang tot Gods wil. De mens luistert naar een sprekende God die zijn morele wil aan ons openbaart (Micha 6:8). Geloof bewerkt een houding van afhankelijkheid en kwetsbaarheid. Maar nog veel meer verandert het ons morele oriëntatiepunt. We lezen de Schrift vanuit de geloofsvraag 'Wie is onze God?' en niet 'Wie ben ik?' of 'Wat moet ik doen?' Volgens Emil Brunner is dit het belangrijkste onderscheid tussen de natuurlijke (filosofische) ethiek en de bijbelse ethiek. Het gaat niet om de zelf-zoekende en naar zichzelf refererende mens. De mens is een zondaar (Rom 3:23) en mag zichzelf niet vertrouwen, ook niet op zijn eigen wettische systemen. Geloof is de aanvaarding van Gods geschenk (1939:54-68).

Gods genadige handelen, zijn bevrijding gaat steeds vooraf aan onze ethiek. Zo beginnen de Tien Woorden: 'Ik ben de HEERE, uw God, Die u uit het land Egypte, uit het slavenhuis, geleid heeft' (Ex 20:2). Gods reddende handelen is enerzijds historisch, feitelijk en concreet. Anderzijds is het een bepaalde lezing van het historische. Het is door geloof dat we Gods hand achter de historische feiten zien. Door het geloof zien we: 'Hij heeft ons getrokken uit de macht van de duisternis en overgezet in het Koninkrijk van de Zoon van Zijn liefde' (Kol 1:13).

Door het geloof onderkennen we hoe God inbreekt in ons eigen morele voor-verstaan. Het gaat niet langer om de mens, maar om de mens die in de woorden van de Schrift door God wordt aangesproken. Dit inbreken illustreerden we al in de inleiding met het bekeringsverhaal van de kerkvader Augustinus. Het interpreterende ik dat zijn weg zelf zoekt, wordt nu een gelovende ik die richting ontvangt. Dit 'voorverstaan' is daarmee ook een 'zelfverstaan', theologisch gesproken dat van een nieuwe identiteit in Christus. Emil Brunner (1939) vat de centrale plaats van geloof voor de Christelijke ethiek krachtig samen:

Das Wort Gottes, sofern es unseren Willen angeht, ist das Gebot Gottes. Im Glauben nimmt us Gott für seinen Willen in Anspruch ... Und nicht anders ist uns das Schenken Gottes bekannt als so, dass er uns im Wort seiner Begnadung zugleich zu sich hin und damit in seinen Dienst ruft. Wir dürfen glauben, wir können glauben - das ist Gottes Gnadenwort; wir sollen glauben - das ist sein Gebot. (p. 97)

Dit geloofsvertrekpunt sluit ethiek als kritische vakdiscipline niet uit. We kunnen het hermeneutisch model het best vergelijken met Anselmus' motto fides quaerens intellectum. Het geloof komt eerst, maar vraagt vervolgens om verdere duiding en reflectie. Het morele 'voorverstaan' maakt onderdeel uit van deze geloofsbeleving, en in de ethiek wordt dit voorverstaan vervolgens onderworpen aan een kritische reflectie. Ethiek, ook theologische ethiek, is altijd betrokken op het geleefde leven, op de moeilijkheden van ons bestaan. Interpretatie kan niet uit onszelf komen als geïsoleerde en ahistorische individuen. We grijpen terug op tradities en verhalen en plaatsen die vervolgens in ons eigen levensverhaal. Vertrekkende vanuit het geloof vormen we voortdurend onszelf. Het geloof is het begin van een kritisch denkproces en niet het einde. Het gaat om een levensweg van voortdurend onderwezen worden, voortdurend bijleren (Bildung): 'Leer mij, HEERE, Uw weg, ik zal in Uw waarheid wandelen, maak mijn hart één om Uw Naam te vrezen' (Ps 86:11). De taal van onze interpretaties vermengt zich met de taal van de Bijbel als Gods woorden.

Verder is het vertrekpunt van het geloof geen gemakkelijkheidsoplossing, een naïeve sprong naar het religieuze. De ultieme vraag is geloof in wie/wat? Wanneer we de transcendente dimensie van ons leven negeren zal God al gauw worden vervangen door een substituut. In dit opzicht is geloof een brede antropologische categorie. De mens geeft betekenis aan de werkelijkheid en maakt morele keuzes vanuit geloofscategorieën. Dit kan bij voorbeeld een rotsvast geloof zijn in het vermogen van het authentieke zelf. De taak van de theologie is juist het onderscheiden wie/wat geloofwaardig en wat niet geloofwaardig is. In de Schrift worden afgoderij en moreel verval heel nauw aan elkaar verbonden. We worden wie/wat we aanbidden. Jezus plaatst ons voor de keuze tussen de Mammon en de Heer (Matt 6:24) en Paulus noemt geldzucht afgoderij (Ef 5:5; Kol 3:5). Afgoden zijn niet alleen blind, ze maken ons blind voor de waarheid van de Schrift. Het ontmaskeren van de valse goden is een belangrijke ethische opdracht (Beale 2008; Ramachandra 2008; Keller 2009). Dit betekent dat een hermeneutische ethiek kritisch reflecteert op onze geloofservaringen en de daaruit volgende waarden.

\section{De context van interpretatie: De kerk in de wereld}

We interpreteren niet als geïsoleerd individu maar als onderdeelvan een groter geheel. Het is juist dehermeneutische opdracht om dit grotere geheel in beeld te brengen. De gemeenschap en de bijhorende tradities vormen steeds de context van ons verstaan. Voor de wijsgerige ethiek benadrukte Gadamer het belang van de traditie in het hermeneutische proces. Volgens Gadamer is het proces van interpretatie geen individuele aangelegenheid, maar ontstaat interpretatie juist in de context van de eigen gemeenschap en de daarbij horende tradities. Een hermeneutische gemeenschap waar onderlinge betrokkenheid heerst, vormt onze identiteit en geeft richting aan onze morele keuzes (2014:308).

De Bijbel is onmiskenbaar het boek van en voor de kerk. Deze kerk wordt de pijler en fundament van Gods waarheid genoemd (1 Tim 3:15). Aandacht voor de rol van de kerk bij het hermeneutische proces geldt zowel lokaal als universeel. Wat het universele en historische betreft is er deherwaardering van de rijke theologische traditie als leessleutel voor de Bijbel. De laatste jaren heeft theologische hermeneutiek opgang gemaakt onder evangelische en reformatorische theologen. (Denk bijvoorbeeld aan het werk van Kevin Vanhoozer 2015 en Joel Green 2011.) Bij de theologische interpretatie hoort een 'ecclesial concern' en wordt de 
'interpretative community' gehonoreerd. Een hermeneutische ethiek is niet zozeer het individu dat interpreteert dan wel het individu dat als onderdeel van een brede en historische geloofsgemeenschap interpreteert. Zo lezen we de Schrift in een breder theologisch (Christocentrisch) kader. Het credo fungeert als een leessleutel voor onszelf en de tekst van de Bijbel. Dogma en credo zijn niet alleen normerend maar vooral vormend door onze gebeden, liederen en liturgie heen. Het spreekt dan ook niet voor zich om al te snel allerlei morele vernieuwingen door te voeren simpelweg omdat tijden en inzichten veranderen.

Op het meer lokale vlak toont Paulus hoe de dialoog binnen de gemeente de context vormt van een hermeneutische proces, zoals bijvoorbeeld in Romeinen 15:12-14:

De God nu van de hoop moge u vervullen met alle blijdschap en vrede in het geloven, opdat $u$ overvloedig bent in de hoop, door de kracht van de Heilige Geest. Nu ben ik ervan overtuigd, mijn broeders - ook ikzelf met het oog op $\mathrm{u}$ - dat $\mathrm{u}$ zelf ook vol bent van goedheid, vervuld met alle kennis, in staat ook elkaar terecht te wijzen.

Paulus toont zijn vertrouwen in de bekwaamheid om elkaar moreel richting te geven. Dit lijkt in contrast te staan met Romeinen 3:10, 11: 'Er is niemand rechtvaardig, ook niet één, er is niemand die verstandig is.' De reformatorische traditie heeft vaak onze onbekwaamheid en zondigheid benadrukt. Hier zien we echter hoe Gods Geest toch werkt doorheen ons menselijk onvermogen. Gods Geest werkt in de geloofsgemeenschap, die daardoor wordt vervuld met hoop en kracht. Juist door het onderlinge gesprek, het delen van verschillende opvattingen, ervaringen en verhalen ontstaat er een morele gemeenschap waar men elkaar raad geeft. Dit is de hermeneutische gemeenschap, waarbij volgens Gadamer in gewetenskwesties geldt: 'Alleen vrienden kunnen elkaar raad geven, of anders gezegd: alleen raad die vriendschappelijk is bedoeld, heeft voor wie raad krijgt zin' (2014:308). Juist door middel van de taal of het gesprek vormen we zulk een gemeenschap: 'Alle vormen van menselijke levensgemeenschap zijn vormen van taalgemeenschap, sterker nog, zij vormen taal' (ibid:424).

Tegenover deze nadruk op gemeenschap staat een neiging tot een individualistische lezing van de bijbel. Het gaat over wat God tot mij hier en nu zegt. Deze individualistische cultuur zou volgens sommigen ingebakken zitten in het protestantisme. Een van de belangrijkste slogans van de reformatie was sola scriptura. Er bestaat onmiskenbaar een nauw verband bestaat tussen het verlangen naar herbronning van de renaissance en herontdekking van de bijbel ten tijde van de reformatie. Een belangrijke vooronderstelling van dit vernieuwende project was het idee dat het individu bekwaam is om Gods waarheid te kennen. In de praktijk leek het erop of het individu ging primeren op de kerk als heilsinstituut. Deze reformatorische nadruk op individualiteit in de morele keuzes werd vervolgens in de moderniteit nog versterkt. Ethiek wordt een individueel rationeel project, ook de christelijke ethiek. De hermeneutische handeling gebeurt dan vanuit het persoonlijke perspectief van de individuele vrijheid en de bijbel is een privé bron. In het licht van deze ontwikkelingen is de seculiere nadruk op individuele zingeving en moraal, en de zoektocht naar persoonlijk geluk evenzeer een kenmerk van hedendaagse christenen.

In het Amerikaanse evangelicalisme, dat ook sterke invloed uitoefent op het evangelicalisme in Europa, werd het individueel begrijpen van de Schrift heel sterk doorgevoerd. De christen wordt persoonlijk geleid door Gods Geest en interpreteert de Bijbel vanuit zijn eigen levensverhaal. Men 'shopt' voor een kerk die past bij de persoonlijke ontplooiing en overtuigen. Christenen zoeken vooral bevestiging bij kerken die inspireren, versterken en troosten. Religiositeit kan zo gemakkelijk wegglijden tot een consumptieproduct. Met een duidelijk gevoel voor dramatiek en over-correctie wil de ethicus Stanley Hauerwas (1993) de Bijbel afnemen aan Amerikaanse, evangelicale individuen:

Most North American Christians assume they have the right, if not obligation, to read the Bible. I challenge that assumption. No task is more important than for the church to take the Bible out of the hands of individual Christians in North America. Let us no longer give the Bible to every child when they enter the third grade or whenever their assumed rise to Christian maturity is marked ... Let us rather tell them and their parents that they are possessed by habits far too corrupt for them to be encouraged to read the Bible on their own. (p. 15)

Hauerwas wil vooral benadrukken dat we de Bijbel alleen verstaan in de context van een oprechte gemeenschap. De Bijbel hoort alleen thuis in het leven van een alternatieve geloofsgemeenschap. Een immoreel leven en onze ondeugden verstoren ons verstaan van de tekst; alleen in een geloofsgemeenschap als tegencultuur verstaan we de Bijbel, aldus Hauerwas. De Bijbel wordt door hem ook eerder als een liturgisch boek gehonoreerd en vanuit deze liturgische beleving vindt er een morele transformatie plaats (Hauerwas \& Wells 2007).

De nadruk op de interpreterende pelgrimsgemeenschap mag ons echter niet isoleren van de wereld rondom ons. Vele ethische vragen ontstaan juist vanuit een contrastervaring met de samenleving. Het is juist 'kerk zijn in de wereld' dat ons bepaalt bij de morele opdracht. Deze vragen hebben te maken met ervaringen van onrecht, verdrukking en geweld. De gemeente leeft als eschatologische gemeenschap te midden van Gods wereld in nood en probeert zo een teken van hoop te zijn. Juist in de ethiek komt de spanning tussen kerk en wereld op scherp te staan. Het is de hoop van Gods Koninkrijk dat zich in de wereld zal manifesteren die ons de actuele feiten op een heel eigen wijze doet interpreteren (Moltmann 2010). De Bijbel is niet het boek van de kerk, maar het is het boek van 'een kerk gezonden in de wereld'. Zoals in de ethiek van Bonhoeffer duidelijk wordt gesteld: 'In Jezus Christus is de werkelijkheid van God binnengegaan in de werkelijkheid van deze wereld' (Bonhoeffer 2012:41). Wanneer Bonhoeffer stelt dat we alleen over God en de wereld juist kunnen spreken dan vanuit Jezus Christus, dan stelt hij een hermeneutische wending voor. Het is juist in de gemeente dat we dit 'ingaan in de wereld' en de morele 
spanningen die daarbij onvermijdelijk horen, beter verstaan. 'De kerk is de plaats waar beleden en serieus genomen wordt dat God de wereld in Christus met zichzelf heeft verzoend, dat God de wereld zo heeft liefgehad, dat Hij de Zoon voor haar heeft opgegeven' (ibid:48).

\section{Het motief tot interpretatie: De liefde als eerste leesregel}

Bepalend voor het hermeneutische proces is onze diepste motivatie. Ook Van der Watt stipt dit aan: 'Etiek gaan oor die doen wat reg en verkeerd is - dit gaan oor dade. Dade is altyd verbonde aan ' $n$ mens se wil. Die wil en motief daaragter speel dus 'n sentrale rol in etiese gedrag' (2014:288). De intenties van ons hart geven richting aan en kleuren ons verstaan van de werkelijkheid. Boven werd reeds gesteld dat het bij hermeneutische ethiek gaat over een doordachte interpretatie van onze morele intuïties en diepere drijfveren.

De bijbel is een boeiende verzameling van historische boeken, een diversiteit aan genres, heel verschillende auteurs en ook een diversiteit aan morele adviezen, geboden, wijsheid en verhalen (Van der Watt 2014:282). Maar het is ook het boek van God, en zodoende weerspiegelt het zijn wezen. Het wezen van onze drie-enige God is liefde, de eeuwige liefde tussen de Vader, Zoon en Geest is de bron van ons heil. Daarom: 'Wie niet liefheeft, kent God niet, want God is liefde' (1 Joh 4:8). Liefde is hier voor Johannes een epistemologische (kennis-) categorie (Van der Watt 2014:303). Alleen door de liefde kent men God die zelf liefde is (Van der Watt 2014:296, 298-305). Wat voor God zelf geldt, geldt ook voor zijn openbaring. Alleen door de liefde kan men de Schrift verstaan (Nullens 2013). Inderdaad, liefde vervult de wet (Rom 13:10; vgl. 1 Kor 16:14; 2 Kor 8:7-8; 2 Kor 8:24a). Hierbij wordt het dubbelgebod van de liefde (Matt 22:33-40) de eerste hermeneutische regel. Het ethische gaat vooraf aan het kennen. Van der Watt heeft dus gelijk wanneer hij stelt dat: 'God is liefde; daarom is liefde uit God. Die gelowige se liefde moet dus die liefde van God weerspieël. Hier is die mimetiese aard van 'n mens se optrede belangrik' (2015:303) (vgl. 1 Joh 4:7-8; 9-11).

De liefde als eerste hermeneutische sleutel is typerend voor de Augustijnse traditie (Pool 2004). Volgens die traditie is ons finale levensdoel als geschapen mens en ons grootste geluk het genieten van Gods liefde. De Bijbel is slechts een voorlopig instrument, een transportmiddel waarmee we ons op die weg verplaatsen. We waarderen de Bijbel in het licht van dit grote doel. Het dubbelgebod van de liefde functioneert bij Augustinus als de belangrijkste hermeneutische sleutel. In zijn hermeneutisch werk: De Doctrina Christiana, schrijft Augustinus (1999) het volgende:

Iedereen die dus denkt de Schrift of een willekeurig gedeelte daarvan te hebben begrepen, maar ondanks dat begrip die tweevoudige liefde, voor God en zijn naaste, niet heeft opgebouwd, heeft de Schrift nog niet begrepen. Iedereen die er een idee aan ontleent dat nuttig is voor de opbouw van deze liefde, maar die niet onder woorden brengt wat de auteur van de bewuste passage kennelijk bedoeld heeft, maakt geen fatale vergissing en liegt absoluut niet ... Nee, iedereen die in de Schrift een andere betekenis aan een passage toekent dan de auteur voorhad, vergist zich, zonder dat de Schrift liegt. Maar, zoals ik boven ter sprake bracht, als zijn vergissing een uitleg oplevert die de liefde opbouwt - het doel van de vermaning, maakt hij zijn fout als iemand die per abuis de gebaande weg verlaat. Hij moet wel tot beter inzicht gebracht worden en uitgelegd krijgen dat het nuttiger is de weg niet te verlaten om niet gewend te raken aan omwegen en zo noodgedwongen op zijpaden of totaal verkeerde paden te komen. (p. 36)

De nieuwtestamenticus Richard Hays wijst op de prominente plaats van Hosea 6:6 in de ethiek van Jezus: 'Want barmhartigheid wil Ik, en geen offer, en meer dan brandoffers, wil Ik kennis van God' (Matt 9:13; Willibrordvertaling 1995). Het is door het tonen van Gods barmhartigheid dat heel de wet wordt vervuld. Dit brengt Hays (1996) tot een 'hermeneutic of mercy', een filter waarmee we de verschillende bijbelse teksten tot ons nemen:

Those who are trained for the kingdom of heaven are trained to evaluate all norms, even the norms of the Law itself, in terms of the criteria of love and mercy. In the community that lives this vision, then, acts of love and mercy should abound. (p. 101)

Net als bij de twee andere oriëntatiepunten, geloof - afgoderij, gemeenschap - individualisme, is er ook hier een donkere zijde. Dit is de verblinding door haat, wrok, kilheid en ressentiment. Ook in de wijsgerige ethiek wordt de verblinding door ressentiment onderkent (o.a. Scheler 2008). Een 'zich afzetten tegen ...', persoonlijke kruistochten of een diepe ergernissen leggen een sluier over de echte betekenis van de Schrift. Kennis op zich kan ons hiervan niet genezen, het is alleen de liefde die doet zien. Henri Nouwen wijst erop hoe een bitter ressentiment bij vele pastors als spiritueel verblindend werkt. Als oplossing benoemt hij niet zozeer de houding van liefde dan wel van dankbaarheid (gratitude). Het gaat niet om een occasioneel danken maar een grondhouding van inzicht in eigen beperkingen en dankbaarheid. Dankbaarheid is waar het in de bediening van een pastor om draait: 'Gratitude is at the heart of celebration and ministry' (2010:58). Het is alleen vanuit een liefde voor God en de medemens dat we toegang krijgen tot de betekenis van de Schrift.

\section{Conclusie}

'Neem en lees!' is onze eerste morele opdracht als discipelen van Jezus. Door het lezen en mediteren van de Bijbel wordt onze eigen morele vooronderstellingen getoetst, bevraagd en gevormd. Het is duidelijk dat een hermeneutische ethiek eerder een bepaalde ruimte of speelveld aangeeft dan dat ze concrete antwoorden biedt op allerlei morele vraagstukken. De belangrijkste uitdaging bij het Schriftgebruik in de ethiek is om steeds deze drie ankerpunten voor ogen te houden: geloof, kerk in de wereld, en de liefde. We hebben immers de vervelende neiging om de Schrift los te trekken van deze drie ankerpunten. Dat een schip woelig meebeweegt met een woelige zee is normaal. De drie ankerpunten zorgen ervoor 
dat het niet op drift geraakt. Het is de opdracht van de 'bedienaar van het Woord' om inzicht te krijgen in het hermeneutische proces en de complexiteit van de werkelijkheid. Het gaat dan vooral om wijsheid en levenskunst met grote gevoeligheid voor de unieke context. Belangrijk hierbij is dat men meer aandacht geeft voor de vormende kracht van de Bijbel en niet alleen de normerende kaders. Door het lezen, onderwijzen, liturgisch gebruik en mediteren van de Bijbel vormt Gods Geest onze interpretatie van de morele werkelijkheid. Bij het aangeven van richting en het vormen van zichzelf en anderen dient men steeds deze drie ankerpunten voor ogen te houden. De Bijbel zegt ons niets zonder geloof, ons samen gemeente zijn in deze wereld, en liefde. In de woorden van Van der Watt: 'In 'n geloofsverhouding met God, in afhanklikheid van die Gees, moet gelowiges telkens die weg van die liefde in elke situasie denkend soek' (2014:304).

\section{Dankwoord}

\section{Tegenstrijdige belangen}

De auteurs verklaren dat zij geen financiële of persoonlijke relaties die ten onrechte hen hebben beïnvloed in het schrijven van dit artikel.

\section{Referenties}

Augustinus, A., 1982, Augustinus' belijdenissen, vertaald door A. Sizoo, Meinema, Delft.

Augustinus, A., 1999, Wat betekent de bijbel?: Christelijke scholing in tekstbegrip en presentatie: De doctrina christiana, ingeleid, vertaald en toegelicht door J. den Boeft en I. Sluiter, Ambo/Anthos BV, Amsterdam.

Beale, G.K., 2008, We become what we worship: A biblical theology of idolatry, Green Press, Downers Grove, IL.

Bonhoeffer, D., 2012, Aanzetten voor een ethiek, samengesteld, vertaald en ingeleid door G. den Hertog en W. Veen, Boekencentrum, Zoetermeer.

Birch, B.C., 2011, 'Ethics, Scripture in Ethics, Methodological Issues', in J.B. Green (ed.), Dictionary of Scripture and Ethics, pp. 27-34, Baker Academic, Grand Rapids, MI.

Brunner, E., 1939, Das Gebot und die Ordnungen: Entwurf einer protestantischtheologischen Ethik, Zwingli-Verlag, Zurich.

Gadamer, H.G., 2014, Waarheid en methode: hoofdlijnen van een filosofische hermeneutiek, vertaald door M. Wildschut, Uitgeverij Vanthilt, Nijmegen.

Green, J.B. (ed.), 2011, Dictionary of Scripture and Ethics, Baker Academic, Grand Rapids, MI.

Hauerwas, S., 1993, Unleashing the Scripture: Freeing the Bible from captivity to America, Abingdon Press, Nashville, TN.

Hauerwas, S. \& Wells, S., 2007, The Blackwell companion to Christian Ethics, Blackwell, Malden.
Hays, R., 1996, The moral vision of the New Testament: Community, cross, new creation - A contemporary introduction to New Testament ethics, Harper One, San Francisco.

Heitink, G., 1993, Praktische theologie: geschiedenis, theorie, handelingsvelden, Kok, Kampen.

Jansen, M., 2002, 'Talen naar God: wegwijzers bij Paul Ricoeur', PhD Dissertatie, Narratio, Gorinchem.

Keller, T., 2009, Counterfeit gods: The empty promises of money, sex, and power, and the only hope that matters, Dutton, New York.

Kuitert, H.M., 1981, 'De rol van de bijbel in de protestantse theologische ethiek', Gereformeerd Theologisch Tijdschrift 81, 65-82.

McGrath, A.E., 1997, The genesis of doctrine: A study in the foundation of doctrinal criticism, Eerdmans, Grand Rapids, MI.

Moran, D. \& Mooney, T., 2002, The phenomenology reader, Routledge, New York.

Moltmann, J., 2010, Ethik der Hoffnung, Gütersloher Verlagshaus, Gütersloh.

Nouwen, H.J.M., Christensen, M.J. \& Laird, R., 2010, Spiritual formation: Following the movements of the spirit, HarperOne, New York.

Nullens, P., 2006, Verlangen naar het goede: bouwstenen voor een christelijke ethiek, Boekencentrum, Zoetermeer.

Nullens, P., 2013, 'Theologia Caritatis and the moral authority of Scripture: Approaching 2 Timothy 3:16-17 with a hermeneutic of love', European Journal of Theology 22(1), 38-49.

Nullens, P., 2014, 'Slim omgaan met ethische dilemma's', Management en Organisatie 5/6, 91-107.

Nullens, P. \& Michener, R.T., 2010, The matrix of Christian ethics: Integrating moral philosophy and theology in a postmodern context, IVP, Colorado Springs, CO.

Pool, J.B., 2004, 'No entrance into truth except through love: Contributions from Augustine of Hippo to a contemporary Christian hermeneutic of love', Review \& Expositor 101(4), 629-666.

Ramachandra, V., 2008, Subverting global myths: Theology and the public issues shaping our world, Green Press, Downers Grove, IL.

Ricoeur, P., 1990, Soi-même comme un autre, Seuil, Paris.

Ricoeur, P., 1986, Du texte à l'action, Seuil, Paris.

Scheler, M., 2008, Het ressentiment in de moraal, vertaald door W. Visser, Boom, Amsterdam.

Stiver, D.R., 2012, Ricoeur and theology, T\&T Clark, London.

Taylor, C., 1985, Human agency and language: Philosophical papers I, Cambridge University Press, Cambridge.

Thiselton, A.C., 1992, New horizons in hermeneutics: The theory and practice of transforming biblical reading, Zondervan, Grand Rapids, MI.

Thiselton, A.C., 2011, 'Wisdom in the Jewish and Christian Scriptures: The Hebrew Bible and Judaism', Theology 114(4), 163-172.

Vanhoozer, K., 2005, The drama of doctrine: A canonical-linguistic approach to Christian theology, Westminster John Knox Press, Louisville, KY.

Van der Watt, J.G., 2015, 'Preface', in M. Nel, J.G. van der Watt \& Fika van Rensburg (eds.), The New Testament in the Greaco-Roman world: Articles in honour of Abe Malherbe, pp. 9-11, Lit Verlag, Zürich.

Van der Watt, J.G., 2014, 'Etiek in die Nuwe Testament: Om anders en vir God te leef', in J.G. van der Watt \& F. Tolmie, Ontdek die Boodskap van die Nuwe Testament, pp. 276-353, CUM, Vereeniging.

van Tongeren, P., 1994, 'Narrativiteit en hermeneutiek in verband met een adequate praktische ethiek', Ethische Perspectieven 4(2), 66-80.

van Tongeren, P., 2012, Leven is een kunst: over morele ervaring, deugdethiek en levenskunst, Klement, Zoetermeer.

Verstraeten, J., 2000, Business ethics: Broadening the perspectives, Peeters, Leuven.

Williams, B., 1985, Ethics and the limits of philosophy, Harvard University Press, Cambridge, MA. 